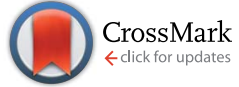

Cite this: Chem. Sci., 2016, 7, 951

Received 28th September 2015 Accepted 26th October 2015

DOI: $10.1039 / \mathrm{c} 5 \mathrm{sc0} 03677 a$

www.rsc.org/chemicalscience

\section{Anticancer metallohelices: nanomolar potency and high selectivity $\dagger$}

\author{
Rebecca A. Kaner, ${ }^{\text {ab }}$ Simon J. Allison, ${ }^{c}$ Alan D. Faulkner, ${ }^{a}$ Roger M. Phillips, ${ }^{\text {*c }}$ \\ David I. Roper, ${ }^{e}$ Samantha L. Shepherd, ${ }^{c}$ Daniel H. Simpson, ${ }^{\text {ae }}$ Nicholas R. Waterfield ${ }^{d}$ \\ and Peter Scott ${ }^{\star a}$
}

\begin{abstract}
A range of new helicate-like architectures have been prepared via highly diastereoselective self-assembly using readily accessible starting materials. Six pairs of enantiomers $\left[\mathrm{Fe}_{2} \mathrm{~L}_{3}\right] \mathrm{Cl}_{4} \cdot n \mathrm{H}_{2} \mathrm{O}(\mathrm{L}=$ various bidentate ditopic ligands $\mathrm{NN}-\mathrm{NN}$ ) show very good water solubility and stability. Their activity against a range of cancer cell lines in vitro is structure-dependent and gives $I_{50}$ values as low as $40 \mathrm{nM}$. In an isogenic pair of HCT116 colorectal cancer cells, preferential activity was observed against cell lines that lack functional p53. Selectivity is also excellent, and against healthy human retinal pigment epithelial (ARPE19) and lung fibroblast (WI38) cells $I_{50}$ values are nearly three orders of magnitude higher. Cisplatin is unselective in the same tests. The compounds also appear to have low general toxicity in a number of models: there is little if any antimicrobial activity against methicillin-resistant Staphylococcus aureus and Escherichia coli; Acanthamoeba polyphaga is unaffected at $25 \mu \mathrm{g} \mathrm{mL}$ $(12.5 \mu \mathrm{M})$; Manduca sexta larvae showed clear evidence of systemic distribution of the drug, and rather than any observation of adverse effects they exhibited a significant mean weight gain vs. controls. Investigation of the mode of action revealed no significant interaction of the molecules with DNA, and stimulation of substantial cell death by apoptosis.
\end{abstract}

\section{Introduction}

The main purpose of current anticancer therapies is to eradicate tumour cells without damaging overall patient health. However, side effects limit the dosage of chemotherapeutic drugs which may be safely applied, and as a result, cancer cells often remain. This leads to poor outcomes in the clinic and the evolution of drug-resistant tumours. ${ }^{1}$ Hence, while the potency of a drug is a very important consideration, drug selectivity towards cancer cells is key to ensuring both safety and effectiveness. ${ }^{2}$ While we might hope that more effective cancer chemotherapies would come from drugs designed to address specific biomolecular targets, ${ }^{2}$ this is far from uniformly the case. ${ }^{3}$ Such drugs may be too targeted since tumours can circumvent the blockade of a specific pathway by switching to another - so-called tumour plasticity. ${ }^{4}$ Compounds with polypharmacology (action against multiple targets) are thus currently of considerable interest to

${ }^{a}$ Department of Chemistry, University of Warwick, Coventry, CV4 7AL, UK. E-mail: peter.scott@warwick.ac.uk

${ }^{b}$ Institute of Advanced Study, University of Warwick, CV4 7HS, UK

${ }^{c}$ School of Applied Sciences, University of Huddersfield, Huddersfield, HD1 3DH, UK ${ }^{d}$ Warwick Medical School, University of Warwick, Coventry, CV4 7AL, UK

${ }^{e}$ School of Life Sciences, University of Warwick, Coventry, CV4 7AL, UK

$\dagger$ Electronic supplementary information (ESI) available: Experimental details, syntheses, biophysical analyses, antimicrobial, anticancer, toxicity, and mechanistic studies. See DOI: 10.1039/c5sc03677a the pharmaceutical industry. This coincides with the resurgence of phenotypic drug discovery, ${ }^{5-7}$ where the targets of a drug are established after the observation of the useful biological effect. This strategy has led to a disproportionately high number of first-in-class drugs with novel mechanisms of action (1999-2008) $)^{8,9}$ The accompanying challenge for synthetic chemistry is to discover, perhaps without reference to some specific biomolecular target, new classes of drug candidates which are both potent and selective.

Lehn recognized the potential of helicates in medicinal chemistry, ${ }^{10}$ and this was borne out in early studies, particularly in the area of cancer. ${ }^{11-15}$ We have argued, ${ }^{16}$ however, that in order for helicates to be capable of translation to the clinic a number of criteria need to be addressed: optical purity and stability, solubility and chemical stability in water, availability on a practical scale, and synthetic diversity. Our recent work has attempted to address these matters ${ }^{17}$ using a new strategy whereby the absolute configurations of individual metal centres are controlled ${ }^{18}$ and linked together to form the prototype helicate-like architectures of Fig. 1. Of these flexicates, ${ }^{19}\left[\mathrm{Fe}_{2} \mathbf{L}_{3}\right]^{4+}$ contains a diamine linker while $\left[\mathrm{Fe}_{2} \mathbf{L}_{3}^{2 \mathbf{a}}\right]^{4+}$ is based on a dialdehyde. ${ }^{19}$ Promising results were reported in a number of disease areas, ${ }^{16,19-21}$ including good activity against a range of cancer cell lines. ${ }^{20}$ Here we report the discovery of a new series of highly potent (40 nM) anticancer compounds of the dialdehyde class related to $\left[\mathrm{Fe}_{2} \mathbf{L}_{3}{ }_{3}\right]^{4+}$ that preferentially kill cancer 


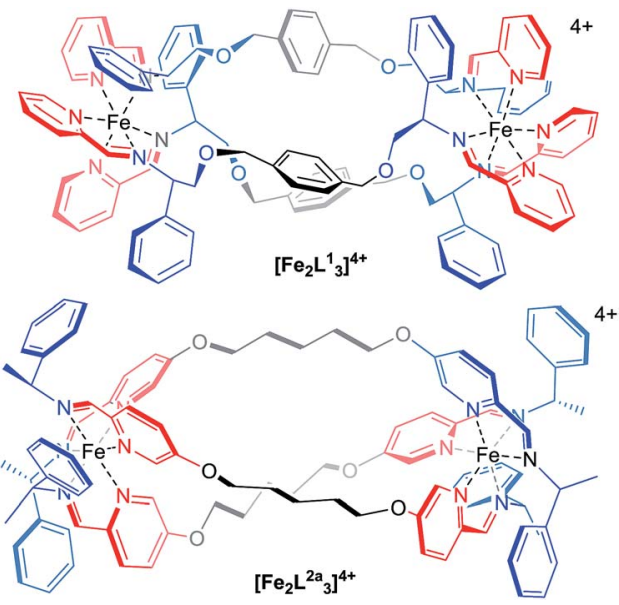

Fig. 1 Structure of flexicates $\left[\mathrm{Fe}_{2} \mathrm{~L}_{3}{ }_{3}\right]^{4+}$ and $\left[\mathrm{Fe}_{2} \mathrm{~L}_{3}{ }_{3}\right]^{4+} .{ }^{19}$

cells that lack functional p53, are nearly three orders of magnitude less toxic to healthy human cell lines tested and have low toxicity to microbes, amoeba and caterpillar larvae.

While DNA does not appear to be the target, the compounds are triggering significant apoptotic cell death as part of their mode of action.

\section{Results}

\section{Synthesis of ligands and $\mathrm{Zn}^{\mathrm{II}}$ systems}

The dialdehyde units of Fig. 2(a) and (b) include various linker rigidities and orientations designed to probe structural viability and biological activity. They were synthesized via simple etherifications of 5-hydoxypicolinaldehyde. ${ }^{22}$

Treatment with $\mathrm{Zn}\left(\mathrm{ClO}_{4}\right)_{2} \cdot 6 \mathrm{H}_{2} \mathrm{O}$ and $(R)$-1-phenylethan-1amine, in appropriate proportions, led to the rapid selfassembly of the bimetallic flexicates in acetonitrile solution at ambient temperature. For the majority of these new $\mathrm{Zn}^{\mathrm{II}}$ complexes NMR spectra indicated that within the limits of the experiment single diastereomers were formed (vide infra).

The sole exception was the 1,3-phenylene system $\Lambda_{\mathrm{Zn}^{-}}$ $\left[\mathrm{Zn}_{2} \mathbf{L}^{2 \mathbf{e}}{ }_{3}\right]\left[\mathrm{ClO}_{4}\right]_{4} \cdot 4 \mathrm{H}_{2} \mathrm{O}$, which gave more complex ${ }^{1} \mathrm{H}$ NMR spectra [Fig. 2(c)]. At $253 \mathrm{~K}$ the phenethylamine methyl group doublet region 1.4-1.7 ppm contains one more intense doublet and two broader signals in the ratio $c a .10: 1: 1$. The proportion of the minor species increases with temperature and the resonances sharpen somewhat, such that by $313 \mathrm{~K}$ two of the smaller doublets corresponding to the minor species are relatively sharp and resolved while a third overlaps with the main resonance. By $353 \mathrm{~K}$ the smaller peaks had again broadened considerably and the ratio of the two sets of resonances was $c a$. $10: 9$. The imine region (8.5-7.6 ppm) behaved in a corresponding manner $(253 \mathrm{~K}$, three peaks in ratio $10: 1: 1: 1$; $353 \mathrm{~K}$, ratio $10: 3: 3: 3$ ). These observations are consistent with the presence of two species - one of high-symmetry and one low - in thermodynamic equilibrium (ratio $c a .1: 0.3$ at low temperature, increasing to almost $1: 1$ at high temperature) but with the involvement of other related conformers particularly at higher temperatures. The processes leading to the observed a)
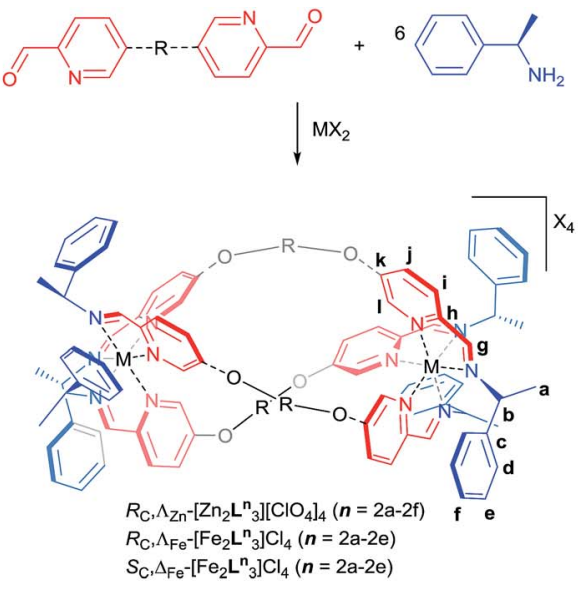

(b)

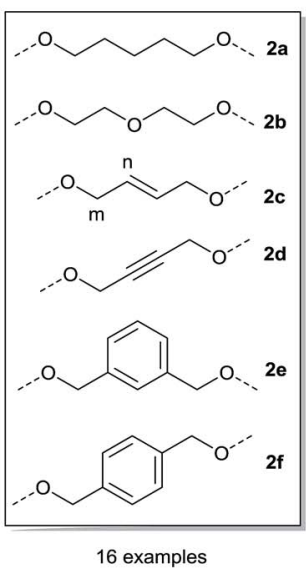

(c)

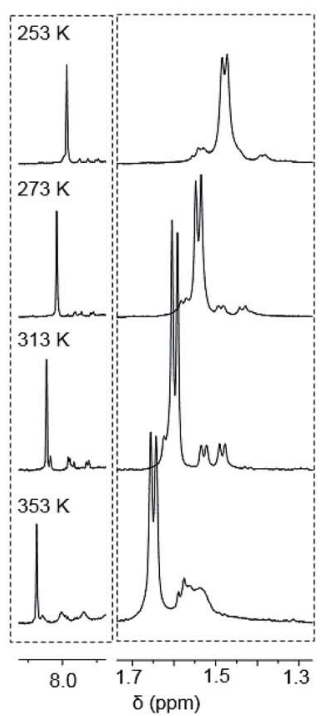

Fig. 2 (a) Synthesis of new flexicates; (b) linking groups used in this study; (c) sections of ${ }^{1} \mathrm{H}$ NMR spectra of $\Lambda_{\mathrm{Zn}}-\left[\mathrm{Zn}_{2} \mathrm{~L}^{2 \mathrm{e}_{3}}\right]\left[\mathrm{ClO}_{4}\right] 4 \cdot 4 \mathrm{H}_{2} \mathrm{O}$ at 253-353 $\mathrm{K}$ in $\mathrm{d}^{3}$-acetonitrile showing the higher equilibrium population of a minor asymmetric conformer at higher temperatures.

NMR behaviour may correspond to exchange between these conformers, or indeed between isostructural low symmetry species. While the spectra are not sufficiently well resolved to determine kinetic parameters, we sought to investigate this molecular system by computational means.

\section{Computational studies}

Following extensive searching, six conformers of $\Lambda_{\mathrm{Zn}}-\left[\mathrm{Zn}_{2} \mathbf{L}_{3}{ }_{3}\right]^{4+}$ were located and minimised [Fig. 3]. These fell into two classes: those where the three $m$-xylenyl groups were oriented away from the central cavity i.e. exo, and those where one such group was oriented endo. No conformers were observed in which two or three $m$-xylenyl groups were oriented into the cavity - this caused too much torsional and steric strain. Structure endo1 was found to be the lowest in energy, the next lowest being endo2 ( $c a .+5 \mathrm{kcal})$ which differs only in the fold of one of the linkers. For these structures the $\mathrm{Zn}-\mathrm{Zn}$ distances are $c a$. 11.7 and $11.8 \AA$ A respectively. The structure exo1 ( $+7 \mathrm{kcal})$ has a large 


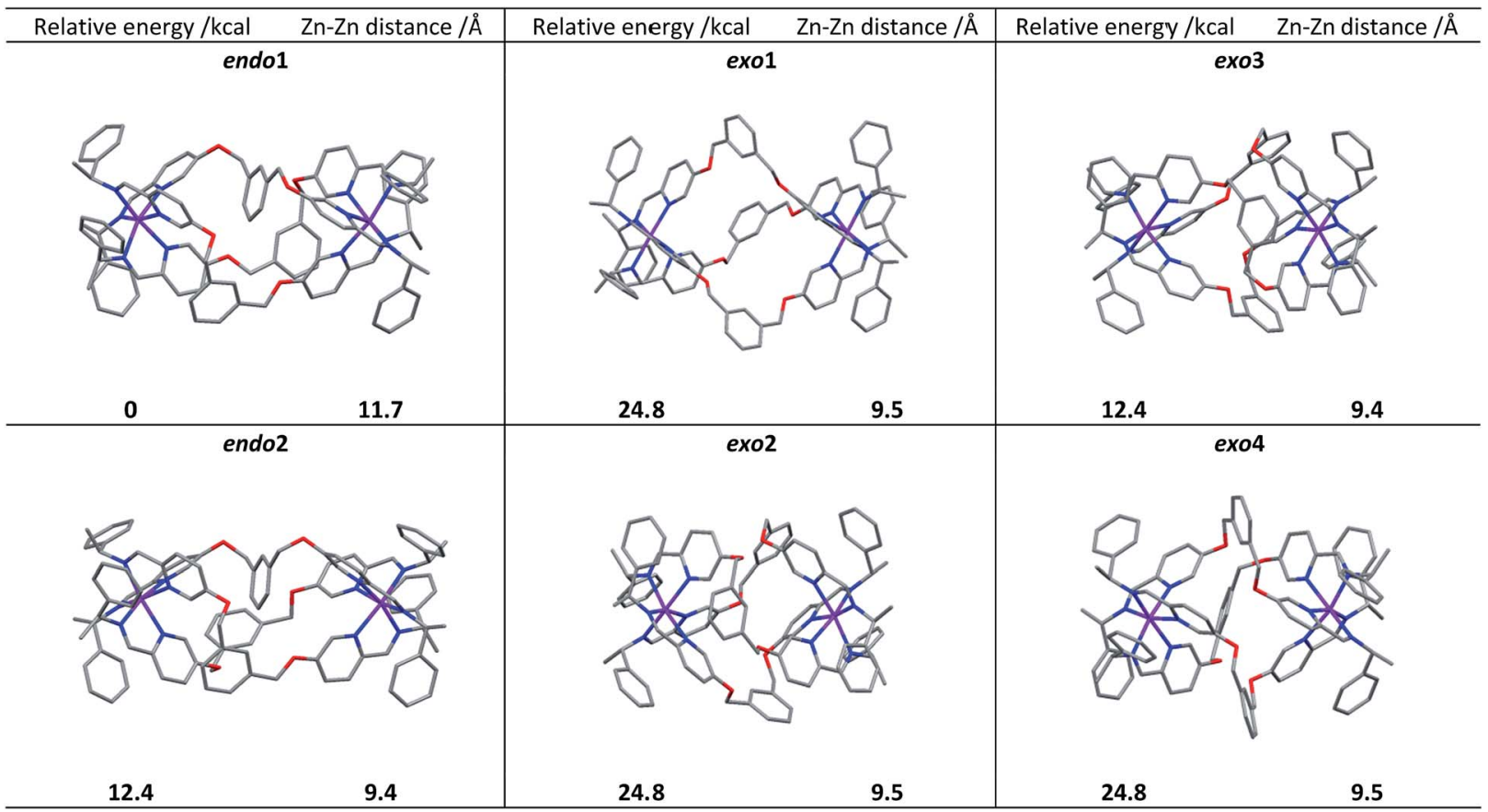

Fig. 3 DFT calculated structures, relative energies (compared to endo1) and $\mathrm{Zn}-\mathrm{Zn}$ distances of the six conformational isomers of $\Lambda_{\mathrm{Zn}}$ - $\left[\mathrm{Zn}{ }_{2} \mathrm{~L}^{2 \mathrm{e}_{3}}\right.$ ] $\left[\mathrm{ClO}_{4}\right]_{4}$.

central cavity but a similar Zn-Zn distance (11.8 ̊̊). The structure exo2 ( $+8 \mathrm{kcal})$ has a considerably shorter $\mathrm{Zn}-\mathrm{Zn}$ distance at ca. $9.5 \AA$ with accompanying concertinaed fold. Furthermore, higher energy conformers exo3 and exo4 differed principally in how the $m$-xylenyl groups folded towards each metal centre. Both were found to have a short $\mathrm{Zn}-\mathrm{Zn}$ distance of 9.4 and $9.5 \AA$ respectively.

While prediction of an equilibrium population from the above calculations is complicated by statistical and entropic contributions from the total number of possible structures and the differences in structural flexibility, the detection of two distinct structural classes is clearly consistent with observations in solution.

We propose that the species detected by NMR displaying high symmetry $\left(D_{3}\right)$ comprises exo conformations while the asymmetric $\left(C_{1}\right)$ species is endo. Examination of the structures indicates that the barrier to conversion within the exo or endo manifolds would be low since it would involve relatively simple concertina-type processes, but conversion between exo and endo conformations requires the rotation of the $m$-xylenyl linker through a strained, high energy transition state.

\section{Synthesis of water soluble compounds}

Pairs of water-soluble $\mathrm{Fe}^{\mathrm{II}}$ flexicate enantiomers $\left[\mathrm{Fe}_{2} \mathbf{L}^{n}{ }_{3}\right] \mathrm{Cl}_{4}(n=$ $2 \mathrm{~b}-2 \mathrm{e})$ were synthesised in high yield by heating the appropriate dialdehyde linker with either $(R)$ - or $(S)$-1-phenylethan-1-amine and $\mathrm{FeCl}_{2}$ in methanol. ${ }^{1} \mathrm{H}$-NMR spectra were similar though slightly broader than the analogous $\mathrm{Zn}^{\mathrm{II}}$ perchlorate complexes and are consistent, along with ${ }^{13} \mathrm{C}-\mathrm{NMR}$ [Fig. 4 and ESI†] and circular dichroism spectra (ESI $\dagger$ ) with the presence of single, stable, non-racemising diastereomers in solution, although unsurprisingly $\left[\mathrm{Fe}_{2} \mathbf{L}^{2 \mathbf{e}}{ }_{3}\right] \mathrm{Cl}_{4}$ exists as a similar mixture of conformers to the $\mathrm{Zn}$ analogue above. The complexes gave excellent electrospray mass spectrometry data e.g. $\Lambda_{\mathrm{Fe}^{-}}-\left[\mathrm{Fe}_{2} \mathbf{L}^{2 \mathbf{2 c}}{ }_{3}\right]$ $\mathrm{Cl}_{4}$ gave a strong peak at $m / z$ 420.17 Da for the tetracationic ion. The formula weights of the panel of complexes, including levels of hydration, were determined by correlation of NMR, IR, thermogravimetric and elemental analyses (see ESI $\dagger$ ). The $p$-xylenyl system $\left[\mathrm{Fe}_{2} \mathbf{L}_{3}{ }_{3}\right] \mathrm{Cl}_{4}$ displayed poor solubility in water and methanol and could not be fully characterised.

\section{Stability in aqueous media}

Absorbance spectra indicated that little decomposition of the flexicates occurred in water at $\mathrm{pH} 7$ over weeks, but half-lives for decomposition could readily be recorded in hydrochloric acid

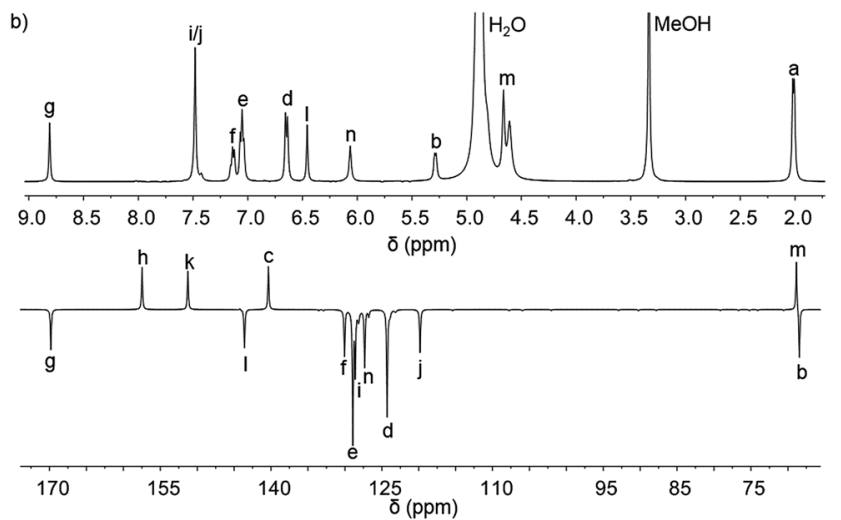

Fig. $4{ }^{1} \mathrm{H}$ and ${ }^{13} \mathrm{C}\left\{{ }^{1} \mathrm{H}\right\}$. NMR spectra of $\Lambda_{\mathrm{Fe}}-\left[\mathrm{Fe}_{2} \mathrm{~L}^{2 \mathrm{C}}{ }_{3}\right] \mathrm{Cl}_{4} \cdot 9 \mathrm{H}_{2} \mathrm{O}$ at $298 \mathrm{~K}$ in $d^{4}$-methanol; see Fig. 2 for key. 
(0.2 M) via the $540 \mathrm{~nm}$ MLCT absorbance band of the complex. Even under such conditions, first order kinetic plots gave $t_{1 / 2}$ values in the region 10-20 h. This very favourable aqueous stability of flexicates probably arises from the presence of extensive (hydrophobic) $\pi$-stacking. ${ }^{23}$

\section{Biological activity \& selectivity}

Cytotoxicity. The activities of the new compounds and cisplatin were investigated in human tumour cell lines: (a) MDA-MB-468 (human epithelial breast adenocarcinoma); ${ }^{24}$ (b) HCT116 p53 ${ }^{+/+}$and (c) HCT116 p53 $3^{-/-} .25$ The HCT116 p53 and HCT116 ${\mathrm{p} 53^{-1-}}^{-}$cancer cells are human colorectal cancer cell lines that are genetically identical (isogenic) except for the presence or absence of functional p53. ${ }^{25}$ These were chosen to enable screening of the effects of p53 status as the loss of p53 function is common genetic event in patient tumours and is strongly associated with increased resistance to many conventional chemotherapeutic agents. ${ }^{25,26}$ In the cisplatin-sensitive $(2.5 \pm 0.5 \mu \mathrm{M})$ MDA-MB-468 cells, the new flexicates showed a range of activities [Fig. 5(a)], with enantiomers of the glycolbridged $\left[\mathrm{Fe}_{2} \mathbf{L}_{3}^{2 \mathbf{b}}\right] \mathrm{Cl}_{4}$ being very potent $(0.2 \pm 0.1 \mu \mathrm{M})$; an order of magnitude more so than cisplatin. Against HCT116 p53 ${ }^{+/+}$ cells [Fig. 5(b)] while cisplatin had a similar activity $(3.5 \pm 1.5$ $\mu \mathrm{M})$ as in the MDA-MB-468 cells, the flexicates were still more potent, with several examples having sub-micromolar activity, e.g. $\left[\mathrm{Fe}_{2} \mathbf{L}^{2 \mathbf{e}}{ }_{3}\right] \mathrm{Cl}_{4}(0.4 \pm 0.1 \mu \mathrm{M})$, and some significant enantiomeric differences were observed. Against HCT116 p53 $3^{-/-}$cells, cisplatin showed less activity $(8.1 \pm 1.8 \mu \mathrm{M})$ than for HCT116 p53 ${ }^{+/+}$cells $(3.5 \pm 1.5 \mu \mathrm{M})$ consistent with the increased resistance of cancer cells lacking p53 to many standard chemotherapeutic agents, while some of the flexicates were extremely active ( $2 \mathrm{a}$ annd $2 \mathrm{c}$ ) with $\mathrm{IC}_{50}$ values in the nanomolar range e.g. $\Delta_{\mathrm{Fe}^{-}}-\left[\mathrm{Fe}_{2} \mathbf{L}_{3}^{2 \mathbf{c}}\right] \mathrm{Cl}_{4}(40 \pm 3 \mathrm{nM})$ [Fig. 5(c)]. Of particular note, flexicates $\Lambda_{\mathrm{Fe}^{-}}\left[\mathrm{Fe}_{2} \mathbf{L}_{3}^{2 \mathbf{c}}\right] \mathrm{Cl}_{4}$ and $\Delta_{\mathrm{Fe}^{-}}\left[\mathrm{Fe}_{2} \mathbf{L}_{3}^{2 \mathbf{c}}\right] \mathrm{Cl}_{4}$ were both 9-fold more active against HCT116 p53 ${ }^{-1-}$ cancer cells than their genetically identical p53 ${ }^{+/+}$counterparts [Fig. 5(b) and(c); see $\mathrm{SEI}]$.

Toxicity in healthy human cells. The most active flexicates in

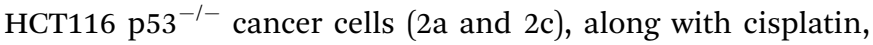
were investigated in human non-cancer retinal pigment epithelial cells (ARPE19) ${ }^{27}$ and normal lung fibroblasts (WI38) [Fig. 5(d)-(e)]. These are healthy human cells with a stable diploid karyotype which senesce after multiple passaging as is characteristic of non-cancer cells. ${ }^{27}$ In Fig. 5(f) we depict an in vitro selectivity index (SI) which compares the activity of these compounds in ARPE19 and HCT116 p53 $3^{-1-}$ cells. While for cisplatin SI was found to be significantly less than 1, meaning that it is actually more toxic to these healthy cells than it is to the cancer cells, the flexicates tested gave SI substantially higher, and for $\Delta_{\mathrm{Fe}^{-}}\left[\mathrm{Fe}_{2} \mathbf{L}_{3}^{2 \mathbf{c}}\right] \mathrm{Cl}_{4} \mathrm{SI}=836 \pm 280$. This excellent selectivity prompted us to investigate the toxicity of the compounds against a number of organisms.

Toxicity to microbes. The compounds were screened against cultures of the gram-positive bacterium methicillin-resistant Staphylococcus aureus, USA300 JE2 (ref. 28 and 29) (MRSA) and the gram-negative Escherichia coli, TOP10 (E. coli). ${ }^{30}$ Kanamycin ${ }^{30}$ was used as a positive control.

The new flexicates had very modest antimicrobial activity (Table 1) or did not significantly inhibit microbial growth at concentrations well over 3 orders of magnitude higher than the $\mathrm{IC}_{50}$ values observed in cancer cells.

Toxicity in amoebae and $M$. sexta larvae. We further tested the potential toxicity of these compounds using a single cell protist organism, the well-established amoeba model
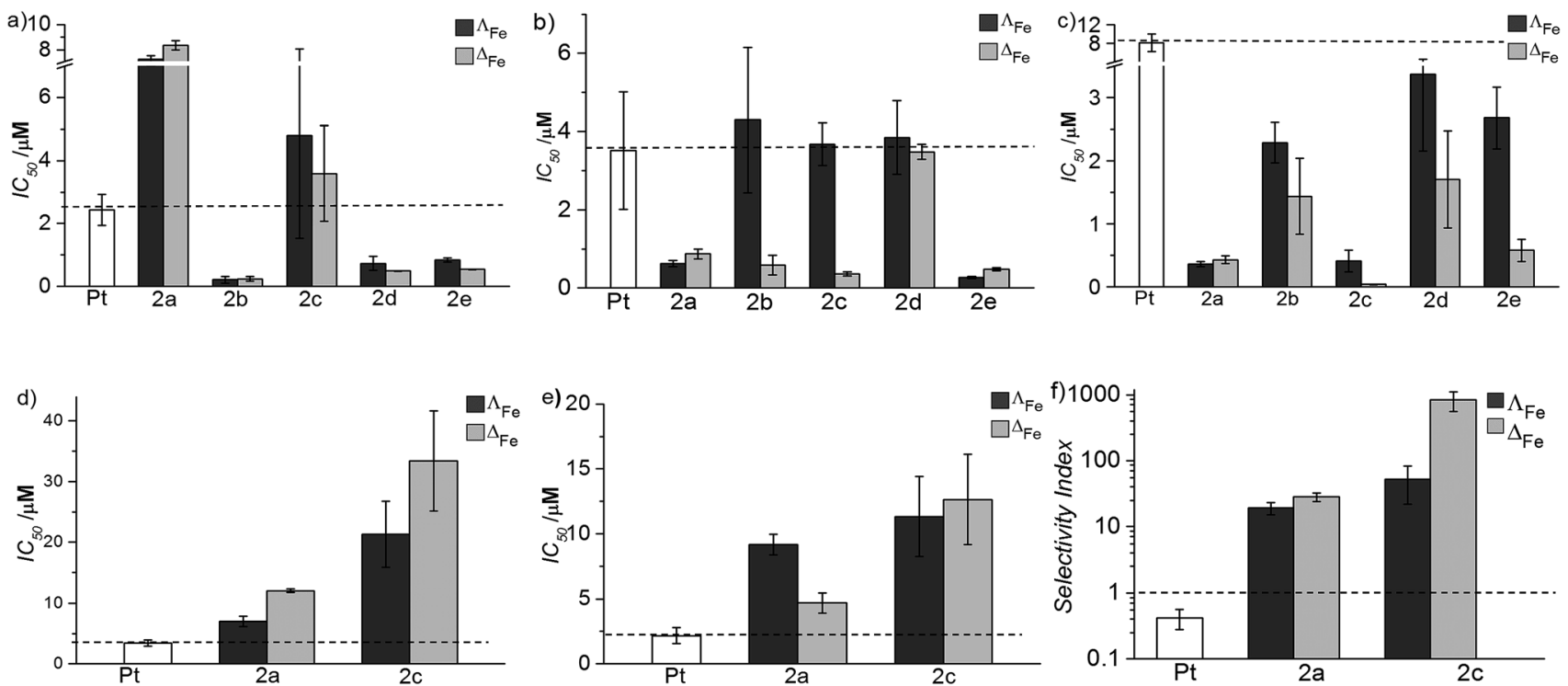

Fig. $5 \quad I C_{50}$ values of cisplatin (Pt, white) and flexicates $\left[\mathrm{Fe}_{2} \mathrm{~L}_{3}\right]_{\mathrm{Cl}}(n=2 \mathrm{a}-2 \mathrm{e})\left(\Lambda_{\mathrm{Fe}}-\right.$ dark grey, $\Delta_{\mathrm{Fe}}-$ light grey) against (a) MDA-MB-468, (b) HCT116 p53 $3^{+/}$, (c) HCT116 p53 ${ }^{-/-}$, (d) ARPE19 and (e) W138 cells over 96 h; dotted line highlights the relative sensitivity of test compounds compared to cisplatin, (f) in vitro selectivity index $\left(\mathrm{IC}_{50}\right.$ ARPE19/IC $50 \mathrm{HCT116} \mathrm{p5}^{-1-}$ ) - broken line at selectivity index $=1$ represents no difference in $\mathrm{IC}_{50}$ between tumour and normal cells - note log scale on $y$ axis. 
Table 1 MIC values for kanamycin and flexicates $\left[\mathrm{Fe}_{2} \mathrm{~L}_{3}{ }_{3}\right] \mathrm{Cl}_{4}(n=2 \mathrm{a}-$ 2e) against MRSA and E. coli, over $20 \mathrm{~h}$ at $37^{\circ} \mathrm{C}$ in Müller-Hinton broth. The approximate concentrations in $\mu \mathrm{M}$ are included for comparison with $\mathrm{IC}_{50}$ data from cancer cell line testing

\begin{tabular}{|c|c|c|c|c|}
\hline \multirow[b]{2}{*}{ Compound } & \multicolumn{2}{|c|}{ MRSA MIC } & \multicolumn{2}{|l|}{ E. coli $\mathrm{MIC}$} \\
\hline & $\left(\mu \mathrm{g} \mathrm{ml} \mathrm{l}^{-1}\right)$ & $(\mu \mathrm{M})$ & $\left(\mu \mathrm{g} \mathrm{ml} l^{-1}\right)$ & $(\mu \mathrm{M})$ \\
\hline Kanamycin & 1 & 2 & 2 & 4 \\
\hline$\Lambda_{\mathrm{Fe}}-\left[\mathrm{Fe}_{2} \mathbf{L}_{3}^{2 \mathbf{a}}\right] \mathrm{Cl}_{4}$ & 64 & 35 & $>128$ & 70 \\
\hline$\Lambda_{\mathrm{Fe}}-\left[\mathrm{Fe}_{2} \mathbf{L}_{3}^{2 \mathbf{b}}\right] \mathrm{Cl}_{4}$ & 128 & 70 & $>128$ & 70 \\
\hline$\Lambda_{\mathrm{Fe}}-\left[\mathrm{Fe}_{2} \mathbf{L}_{3}^{2 \mathbf{c}}\right] \mathrm{Cl}_{4}$ & 128 & 70 & $>128$ & 70 \\
\hline$\Lambda_{\mathrm{Fe}}-\left[\mathrm{Fe}_{2} \mathbf{L}^{2 \mathbf{d}_{3}}\right] \mathrm{Cl}_{4}$ & $>128$ & 70 & 64 & 35 \\
\hline$\Lambda_{\mathrm{Fe}}-\left[\mathrm{Fe}_{2} \mathbf{L}^{2 \mathbf{e}}{ }_{3}\right] \mathrm{Cl}_{4}$ & 64 & 35 & 128 & 70 \\
\hline
\end{tabular}

Acanthamoeba polyphaga. Concentrations of $2.5 \mu \mathrm{g} \mathrm{mL}^{-1}$ $(1.25 \mu \mathrm{M})$ and $25 \mu \mathrm{g} \mathrm{mL} \mathrm{m}^{-1}(12.5 \mu \mathrm{M})$ showed no adverse effect on the amoeba development (see ESI†) also suggesting no broadspectrum toxicity.

Oral and systemic toxicity of these flexicates was assessed in neonate larvae of Manduca sexta. ${ }^{31}$ Caterpillars which had ingested a solution of $25 \mu \mathrm{g} \mathrm{mL}^{-1}[12.5 \mu \mathrm{M}],\left[\mathrm{Fe}_{2} \mathbf{L}_{3}^{2 \mathbf{a}}\right] \mathrm{Cl}_{4}$ in artificial diet for $7 \mathrm{~d}\left[\mathrm{Fe}_{2} \mathbf{L}_{3}^{\mathbf{2 a}}\right] \mathrm{Cl}_{4}$ showed comparable weight gain to controls suggesting no oral toxicity and no adverse effect on feeding behaviour (Fig. 6). Interestingly the larvae exhibited an increased mean weight gain of approximately $30 \%(P<1)$. Also we noted that larvae that ingested the flexicate solutions turned a bright purple colour over the course of the assay, suggesting that these compounds were persisting in the insect and not being rapidly metabolized or excreted.

Systemic toxicity was further tested by injection of $50 \mu \mathrm{g}$ $(0.25 \mu \mathrm{M})$ of the compounds directly into the hemocoel of cohorts of $5^{\text {th }}$ instar larvae $(n=3)$. The cohorts were then allowed to continue feeding. Despite becoming purple, all larvae proceeded to develop into the pupal diapause stage as per the buffer control injections.

\section{Mode of action}

The mode or modes of action of such a new and different system will require intensive investigation and is likely to involve multiple targets and pathways. Here, we describe two preliminary studies towards this end.

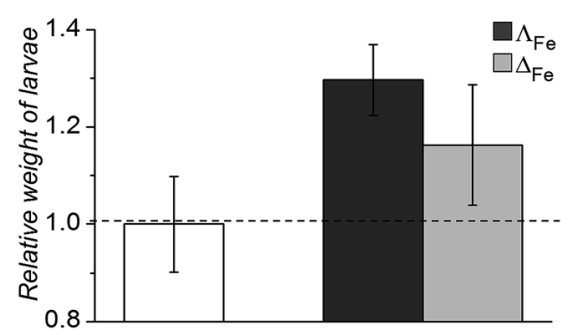

Fig. 6 Relative weight of Manduca sexta larvae after treatment (7d) with $\left[\mathrm{Fe}_{2} \mathrm{~L}^{2 \mathrm{a}_{3}}\right] \mathrm{Cl}_{4}\left(\Lambda_{\mathrm{Fe}}-\right.$ dark grey, $\Delta_{\mathrm{Fe}}-$ light grey $)$ compared to an untreated control.
Denaturation of ct-DNA. We have previously concluded that the induction of DNA damage is not involved in the mode of action of earlier flexicates, despite particular examples binding in a cell free environment. ${ }^{20,32,33}$ We investigated the effect that the new flexicates had on the denaturation temperature $\left(T_{\mathrm{m}}\right)$ of ct-DNA to screen for any indications of DNA binding.

Isolated ct-DNA $\left(0.5 \mathrm{mg} \mathrm{mL}^{-1}\right)$ was mixed with each flexicate $(7.5 \mu \mathrm{M})$ in buffered conditions $(10 \mathrm{mM}$ tris, $1 \mathrm{mM}$ EDTA at $\mathrm{pH}$ 7.0), to give 10 bases: 1 flexicate complex, and the absorbance at $260 \mathrm{~nm}$ between $25{ }^{\circ} \mathrm{C}$ and $90{ }^{\circ} \mathrm{C}$ was recorded $\left(0.4{ }^{\circ} \mathrm{C} \mathrm{min}{ }^{-1}\right)$. $T_{\mathrm{m}}$ for each experiment was calculated from the first derivative of a Boltzmann sigmoidal fit of the plot of absorbance versus temperature.

$T_{\mathrm{m}}$ of untreated ct-DNA $\left(0.25 \mathrm{mg} \mathrm{mL}^{-1}\right.$ in $10 \mathrm{mM}$ tris, $1 \mathrm{mM}$ EDTA at pH 7.0) was measured to be $68.3 \pm 0.5{ }^{\circ} \mathrm{C}$. Most of the new flexicates had no significant effect on the denaturation of ct-DNA (Fig. 7); the small $\left(\Delta T c a .1^{\circ} \mathrm{C}\right)$ reduction for $\mathbf{L}^{2 \mathbf{e}}$ enantiomers can be ascribed to an electrostatic effect. ${ }^{34}$ We are therefore satisfied that DNA is unlikely to be the target of this panel of compounds.

Induction of cell death by apoptosis. The chemosensitivity observed could be due to cytostatic or cytotoxic effects, and cell death can occur by several different mechanisms. These include programmed cell death by apoptosis, inflammatory necrosis, autophagy or 'self-eating', necroptosis and pyroptosis. ${ }^{35}$ One of the hallmarks of cancers is the evasion of apoptosis, thus enabling the long-term survival and proliferation of cancer cells. ${ }^{36}$ We thus investigated whether the most active flexicates are stimulating apoptotic death in cancer cells as part their mode of action.

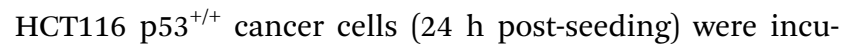
bated in fresh media containing flexicate or no flexicate (control) and were then analysed after $48 \mathrm{~h}$ for levels of apoptosis and necrosis. As cells start to undergo apoptosis, one of the first cellular changes is the externalisation of the membrane protein phosphatidylserine (PS). This can be detected and quantified by fluorescently labelled annexin $\mathrm{V}^{37,38}$ which can selectively bind externally exposed PS but is membraneimpermeable. This enables cells in the early stages of apoptosis to be distinguished from necrotic cells and cells in the late stages of apoptosis both of which have lost membrane integrity and will therefore also stain with the membrane-impermeable DNA stain propidium idodide. ${ }^{39}$

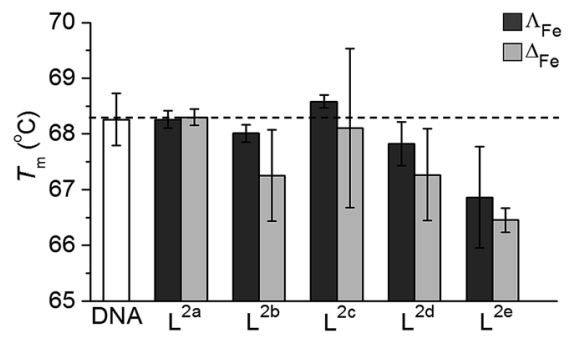

Fig. 7 Effect on $T_{m}$ of linear ct-DNA (DNA, white) from interactions $\left[\mathrm{Fe}_{2} \mathrm{~L}_{3}\right] \mathrm{Cl}_{4}(n=2 \mathrm{a}-2 \mathrm{e})\left(\Delta_{\mathrm{Fe}}-\right.$ light grey, $\Lambda_{\mathrm{Fe}}-$ dark grey) in $1 \mathrm{mM}$ Trizma base (10 base pairs of DNA to 1 flexicate complex). 
Flexicates $\Lambda_{\mathrm{Fe}}\left[\mathrm{Fe}_{2} \mathbf{L}_{3}^{2 \mathbf{a}}\right] \mathrm{Cl}_{4}$ and $\Delta_{\mathrm{Fe}}\left[\mathrm{Fe}_{2} \mathbf{L}_{3}^{\mathbf{2 a}}\right] \mathrm{Cl}_{4}$ were tested and both induced significant levels of apoptosis that were $\sim 2.6$ fold $\left(\Lambda_{\mathrm{Fe}^{-}}\left[\mathrm{Fe}_{2} \mathbf{L}_{3}^{2 \mathrm{a}}\right] \mathrm{Cl}_{4}\right)$ and $\sim 4.4$ fold $\left(\Delta_{\mathrm{Fe}}-\left[\mathrm{Fe}_{2} \mathbf{L}_{3}{ }_{3}^{2 \mathbf{a}}\right] \mathrm{Cl}_{4}\right)$ above background control levels in the HCT116 cancer cells at 48h (Fig. 8). A significant proportion of late apoptotic/necrotic cells were also detectable by $48 \mathrm{~h}$, with levels $\sim 2.3-2.5$ fold above background control levels (Fig. 8). These preliminary investigations indicate induction of apoptosis by these new flexicates as part of their mode of action.

\section{Experimental}

\section{Synthesis}

(E)-5,5'-(But-2-ene-1,4-diylbis(oxy))dipicolinaldehyde $(0.13 \mathrm{~g}$, $0.44 \mathrm{mmol})$ and $(R)$-1-phenylethan-1-amine $(0.11 \mathrm{~g}, 0.88 \mathrm{mmol})$ were dissolved in acetonitrile $(10 \mathrm{~mL})$ with $\mathrm{Zn}^{\text {II }}$ perchlorate hexahydrate $(0.11 \mathrm{~g}, 0.29 \mathrm{mmol})$ and the solution was stirred at ambient temperature for $20 \mathrm{~h}$. Ethyl acetate was added dropwise to cause precipitation of a white crystalline solid, $\Lambda_{\mathrm{Zn}^{-}}$$\left[\mathrm{Zn}_{2} \mathbf{L}_{3}^{2 \mathrm{c}}\right]\left[\mathrm{ClO}_{4}\right]_{4} \cdot 10 \mathrm{H}_{2} \mathrm{O}$. Yield $0.214 \mathrm{~g}, 57 \% .{ }^{1} \mathrm{H} \mathrm{NMR}(400 \mathrm{MHz}$, $\left.298 \mathrm{~K}, \mathrm{CD}_{3} \mathrm{CN}\right) \delta_{\mathrm{H}} 8.06(6 \mathrm{H}, \mathrm{s}, \mathrm{CHN}), 7.49\left(6 \mathrm{H}, \mathrm{dd},{ }^{3} J_{\mathrm{HH}}=8.5 \mathrm{~Hz}\right.$, $\left.{ }^{4} J_{\mathrm{HH}}=3.5 \mathrm{~Hz}\right), 7.36\left(6 \mathrm{H}, \mathrm{d},{ }^{3} J_{\mathrm{HH}}=8.5 \mathrm{~Hz}\right), 7.14\left(6 \mathrm{H}, \mathrm{d},{ }^{3} J_{\mathrm{HH}}=\right.$ $3.5 \mathrm{~Hz}), 7.09\left(6 \mathrm{H}, \mathrm{t},{ }^{3} J_{\mathrm{HH}}=8.0 \mathrm{~Hz}\right), 6.95\left(12 \mathrm{H}, \mathrm{t},{ }^{3} J_{\mathrm{HH}}=7.5 \mathrm{~Hz}\right)$, $6.64\left(12 \mathrm{H}, \mathrm{d},{ }^{3} \mathrm{~J}_{\mathrm{HH}}=7.0 \mathrm{~Hz}, \mathrm{Ar}\right), 6.12(6 \mathrm{H}, \mathrm{m}), 5.38\left(6 \mathrm{H}, \mathrm{q},{ }^{3} J_{\mathrm{HH}}=\right.$ $6.5 \mathrm{~Hz}, \mathrm{CH}), 4.64\left(12 \mathrm{H}, \mathrm{s}, \mathrm{CH}_{2}\right), 1.61\left(18 \mathrm{H}, \mathrm{d},{ }^{3} \mathrm{~J}_{\mathrm{HH}}=6.5 \mathrm{~Hz}\right) .{ }^{13} \mathrm{C}$ $\left\{{ }^{1} \mathrm{H}\right\}$ NMR (101 MHz, $\left.298 \mathrm{~K}, \mathrm{CD}_{3} \mathrm{CN}\right) \delta_{\mathrm{C}} 161.8$ (CHN), 159.6, 142.0, 139.9, 139.4, 132.3 (Ar), $129.7(\mathrm{CH}), 129.4,128.5,126.4$, 122.7 (Ar), $69.7\left(\mathrm{CH}_{2}\right), 64.7(\mathrm{CH}), 23.6\left(\mathrm{CH}_{3}\right)$. MS (ESI) $\mathrm{m} / z 411$ $\left[\mathrm{Zn}_{2} \mathrm{~L}_{3}\right]^{4+}$. IR $\nu \mathrm{cm}^{-1} 2976 \mathrm{w}, 1570 \mathrm{~m}, 1316 \mathrm{~m}, 1225 \mathrm{~m}, 1082 \mathrm{~s}$, $762 \mathrm{w}, 703 \mathrm{~m}, 653 \mathrm{~m}$. Elemental analysis found (calculated for $\left.\mathrm{C}_{96} \mathrm{H}_{96} \mathrm{Cl}_{4} \mathrm{~N}_{12} \mathrm{O}_{22} \mathrm{Zn}_{2} \cdot 10 \mathrm{H}_{2} \mathrm{O}\right) \% \mathrm{C} 51.08$ (51.88), H $4.82(5.26), \mathrm{N}$ 7.38 (7.56).

(E)-5,5'-(But-2-ene-1,4-diylbis(oxy))dipicolinaldehyde (0.1 g, $0.32 \mathrm{mmol})$ and $(R)$-1-phenylethan-1-amine (0.08 g, $0.63 \mathrm{mmol})$ were dissolved in methanol with $\mathrm{Fe}^{\mathrm{II}}$ chloride $(0.03 \mathrm{~g}, 0.21$ mmol). The solution was stirred at reflux $\left(75^{\circ} \mathrm{C}\right)$ for $48 \mathrm{~h}$ and all volatiles were removed under reduced pressure to yield a dark purple solid, $\Lambda_{\mathrm{Fe}}-\left[\mathrm{Fe}_{2} \mathbf{L}^{2 \mathrm{c}}{ }_{3}\right] \mathrm{Cl}_{4} \cdot 9 \mathrm{H}_{2} \mathrm{O}$. Yield $0.388 \mathrm{~g}, 97 \% .{ }^{1} \mathrm{H}$ NMR (400 MHz, $298 \mathrm{~K}, \mathrm{MeOD}) \delta_{\mathrm{H}} 8.80(6 \mathrm{H}, \mathrm{s}, \mathrm{CHN}), 7.47(6 \mathrm{H}, \mathrm{s})$, $7.13\left(6 \mathrm{H}, \mathrm{t},{ }^{3} J_{\mathrm{HH}}=7.0 \mathrm{~Hz}\right), 7.04\left(12 \mathrm{H}, \mathrm{t},{ }^{3} J_{\mathrm{HH}}=7.0 \mathrm{~Hz}\right), 6.64$ $\left(12 \mathrm{H}, \mathrm{d},{ }^{3} \mathrm{~J}_{\mathrm{HH}}=7.0 \mathrm{~Hz}\right), 6.44(6 \mathrm{H}, \mathrm{s}), 6.05(6 \mathrm{H}, \mathrm{s}, \mathrm{Ar}), 5.26(6 \mathrm{H}, \mathrm{q}$, $\left.{ }^{3} J_{\mathrm{HH}}=6.0 \mathrm{~Hz}, \mathrm{CH}\right), 4.65\left(12 \mathrm{H}, \mathrm{s}, \mathrm{CH}_{2}\right), 4.59(6 \mathrm{H}, \mathrm{br} \mathrm{s}, \mathrm{CH}), 1.99$ $\left(18 \mathrm{H}, \mathrm{d},{ }^{3} J_{\mathrm{HH}}=6.0 \mathrm{~Hz}, \mathrm{CH}_{3}\right) \cdot{ }^{13} \mathrm{C}\left\{{ }^{1} \mathrm{H}\right\} \operatorname{NMR}(101 \mathrm{MHz}, 298 \mathrm{~K}$,

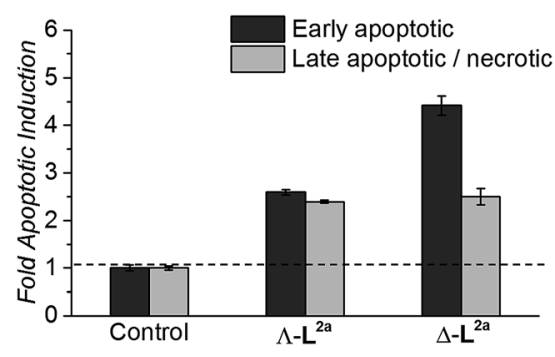

Fig. 8 Induction of apoptosis in HCT116 p53 $3^{+/+}$cancer cells by $48 \mathrm{~h}$ treatment with the indicated flexicates. Fold change shown relative to basal apoptotic levels in untreated HCT116 control cells.
MeOD) $\delta_{\mathrm{C}} 171.0(\mathrm{CHN}), 158.8,152.5,144.8,141.7,131.2,130.1$, 129.8, 128.5, 125.5 (Ar), $121.0(\mathrm{CH}), 70.0\left(\mathrm{CH}_{2}\right), 69.6(\mathrm{CH}), 26.1$ $\left(\mathrm{CH}_{3}\right)$. MS (ESI) $m / z 406\left[\mathrm{Fe}_{2} \mathrm{~L}_{3}\right]^{4+}, 505[\mathrm{~L}+\mathrm{H}] . \mathrm{IR} \nu \mathrm{cm}^{-1} 3352 \mathrm{br}$ s, 2970 br s, 1589 s, 1557 w, 1488 w, 1381 m, 1299 s, 1067 m, $1028 \mathrm{~m}, 760 \mathrm{~m}, 699 \mathrm{~s}, 562 \mathrm{w}$. Elemental analysis found (calculated for $\mathrm{C}_{96} \mathrm{H}_{96} \mathrm{Cl}_{4} \mathrm{Fe}_{2} \mathrm{~N}_{12} \mathrm{O}_{6} \cdot 9 \mathrm{H}_{2} \mathrm{O}$ ) \% C 59.92 (59.76), H 5.84 (5.96), N 8.63 (8.71).

\section{Molecular modelling}

Models of a number of possible conformers of $\Lambda_{\mathrm{Zn}}$ - $\left[\mathrm{Zn}_{2} \mathbf{L}^{2 \mathbf{e}}{ }_{3}\right]$ $\left[\mathrm{ClO}_{4}\right]_{4}$ were constructed and optimised. Starting points for geometry optimisations were taken from crystallographic data. Monometallic structures were first optimised using the B3LYP$\mathrm{D} 3(\mathrm{BJ})^{40}$ functional and the $6-31 \mathrm{~g} *$ basis set, with convergence criteria of 0.0001 a.u. as implemented in the Firefly quantum chemistry package, ${ }^{41}$ which is partially based on the GAMESS(US) source code. ${ }^{42}$ Bimetallic systems were optimised using ligand field molecular mechanics (LFMM) ${ }^{43}$ as implemented in the DommiMOE program, ${ }^{44}$ before being annealed at $500 \mathrm{~K}$ for $1 \mathrm{~ns}$ prior to re-optimisation. Single point energy calculations of all structures were performed using the B3LYP-D3(BJ) ${ }^{\mathbf{4 0}}$ functional and the deff2-TZVP basis set with energy convergence criteria of 0.0001 a.u. as implemented in the Firefly quantum chemistry package. ${ }^{\mathbf{1 1}}$ The calculations were conducted by employing the RIJCOSX approximation with SCF convergence criteria set to 'tight', both of which are defined internally as part of the ORCA DFT quantum chemistry package. ${ }^{45}$ Where relevant, acetonitrile solvate correction was performed using the conductor-like screening model (COSMO) ${ }^{46}$ as implemented in ORCA. $^{45}$

\section{Biological activity}

MIC values were established using a macro broth dilution method in cation-adjusted Müller-Hinton (MH) broth. 96-well plates $\left(200 \mu \mathrm{L}\right.$ of $\left.128 \mu \mathrm{g} \mathrm{mL}{ }^{-1}, 64 \mu \mathrm{M}\right)$ complex in $\mathrm{MH}$ broth, diluted $2^{n} \mu \mathrm{g} \mathrm{mL}^{-1}$, inoculated with each bacterial strain $\left(10^{3} \mathrm{cfu} \mathrm{mL}^{-1}\right)$ were sealed and growth was monitored over $20 \mathrm{~h}$ at $37^{\circ} \mathrm{C}$ with an iEMS 96-well plate reader (see $\mathrm{ESI} \dagger$ ).

$\mathrm{IC}_{50}$ values were determined by incubating cells in 96-well plates $\left(2.0 \times 10^{3}\right.$ cells per well) for $24 \mathrm{~h}$ at $37{ }^{\circ} \mathrm{C}, 5 \% \mathrm{CO}_{2}$ prior to drug exposure. Compounds were added $(100 \mu \mathrm{M}$ to $5 \mathrm{nM}$ in cell medium) for a further 96 h. 3-(4,5-Dimethylthiazol-1-yl)-2,5diphenyl tetrazolium bromide solution $\left(0.5 \mathrm{mg} \mathrm{mL}^{-1}, 20 \mu \mathrm{L}\right.$ per well) was added for a final $4 \mathrm{~h}$. Upon completion all solutions were aspirated, dimethyl sulfoxide $(150 \mu \mathrm{l})$ was added and absorbance $(540 \mathrm{~nm})$ was recorded with a Thermo Scientific Multiskan EX microplate photometer.

Oral toxicity was established by feeding cohorts of Manduca $\operatorname{sexta}^{31}$ one-day-old neonate larvae with each flexicate $(25 \mu \mathrm{g}$ $\mathrm{mL}^{-1}$ in artificial wheat germ diet) for $7 \mathrm{~d}$ at $28{ }^{\circ} \mathrm{C}$ and weighing to assess growth rate. Systemic toxicity assays ${ }^{47}$ were conducted by injecting an ethanol $(70 \% \mathrm{v} / \mathrm{v})$ swabbed region of first day fifth instar M. sexta larvae with each flexicate $\left(0.5 \mathrm{mg} \mathrm{mL}^{-1}\right.$ $[0.25 \mu \mathrm{M}]$ in PBS), before allowing them to continue feeding for $7 \mathrm{~d}$ at $28{ }^{\circ} \mathrm{C}$, using physical stimulus to assess their status. 


\section{Mode of action}

Denaturation of ct-DNA was measured by mixing ct-DNA $\left(0.5 \mathrm{mg} \mathrm{mL} \mathrm{m}^{-1}, 7.5 \times 10^{-5}\right.$ per base, as determined by absorbance at $200 \mathrm{~nm})$ with each complex $(7.5 \mu \mathrm{M})$ in buffered conditions (10 mM tris, $1 \mathrm{mM}$ EDTA at pH 7.0) to give 10 base: 1 complex. The absorbance at $260 \mathrm{~nm}$ as a function of temperature (every $1{ }^{\circ} \mathrm{C}, 25-90{ }^{\circ} \mathrm{C}$ ) was measured in a $1 \mathrm{~cm}$ masked quartz cuvette at a rate of $0.4{ }^{\circ} \mathrm{C} \mathrm{min}^{-1}$ and run in triplicate. $T_{\mathrm{m}}$ was calculated from the first derivative of a Boltzmann sigmoidal fit of the plot of absorbance at $260 \mathrm{~nm}$ against temperature for each complex.

Induction of apoptosis was determined by incubating HCT116 p53 ${ }^{+/+}$cells $\left(5 \times 10^{5}\right.$ cells/flask, $10 \mathrm{~mL}$ complete RPMI1640 medium) for $24 \mathrm{~h}$ at $37^{\circ} \mathrm{C}$ in $5 \% \mathrm{CO}_{2}$, before treating with each flexicate $(20 \mu \mathrm{M}$ in fresh complete media for $48 \mathrm{~h})$ or fresh media containing no drug (control). The supernatant containing any non-adhered, floating cells was then collected and pooled with cells harvested by trypsinisation. This pooled single cell suspension was washed twice with PBS and incubated with propidium iodide and Annexin-V-FLUOS (Roche) to stain apoptotic cells in accordance with the manufacturer's instructions. The proportion of early stage apoptotic cells and late stage apoptotic/necrotic cells were then quantified by flow cytometry as previously described. ${ }^{37,38}$

\section{Conclusions}

Our approach to metallohelix assembly has allowed us to generate a panel of biologically-compatible enantiomers incorporating various bridging groups. This was possible because in this so-called flexicate platform the stereochemistry of the metal complex units is predetermined very efficiently and largely independently of the bridges, and by a mechanism that also provides water-compatibility. ${ }^{23,48}$ In contrast, in a conventional "helication" approach the bridging units are structure-determining, so a mechanism of stereoselection would need to be designed for each example. A further advantage of the flexicate platform is beginning to emerge in that we may be able to develop asymmetric molecules from symmetric ligands via the kinds of conformational abnormalities caused by bridges that partially oppose the predetermined stereochemistry e.g. $\mathbf{L}^{2 \mathbf{e}}$. We have already shown that asymmetric (as opposed to merely chiral) optically pure assemblies are available using directional ligands. ${ }^{49}$ Further, this modular self-assembling system will allow us to probe the effects of peripheral functionality and lipophilicity.

The activity of these new assemblies against cancer cells is strongly dependent on structure, with a range of potencies from $30 \mu \mathrm{M}$ to as low as $40 \mathrm{nM}$. The most active compound $\Delta_{\mathrm{Fe}^{-}}$ $\left[\mathrm{Fe}_{2} \mathbf{L}_{3}^{2 \mathbf{c}}\right] \mathrm{Cl}_{4}$ shows a selectivity index (versus healthy cell lines) approaching $10^{3}$, demonstrating superiority over the clinically used anticancer drug cisplatin in vitro $(\mathrm{SI}<1)$. This selectivity is substantiated in tests with various models; bacteria and amoeba exposed to high concentrations were essentially unaffected, and in Manduca sexta larvae, where the systemic stability of the drug is evidenced, there is arguably a pro-biotic effect i.e. the insects appear to thrive.

In respect of mechanism or mode of action, the lack of binding to DNA indicates that this is unlikely to be the general target in this panel. In fact only one early flexicate ${ }^{19}\left(\left[\mathrm{Fe}_{2} \mathbf{L}_{3}\right]^{4+}\right.$, Fig. 1) in our growing library shows significant interactions with nucleic acids, and while there are fascinating selectivities with various motifs ${ }^{19,32,33}$ there is no DNA damage akin to that induced by e.g. platinum drugs and alkylators. ${ }^{34,49}$ Instead, relevant examples of protein interaction and enzyme inhibition have been characterised. ${ }^{21,32}$ To achieve drug safety and cancer selectivity, mechanistic classes which do not involve induction of DNA damage are attractive, and this may well be the source of the excellent selectivities we describe in this manuscript. Mode of action studies indicate that these compounds can induce substantial cell death by apoptosis independent of any DNA damage. Extensive studies are now required to understand how this complex process, normally subverted in cancers, is induced by these compounds. The above observations of remarkable selectivity alongside very high potency and large enantiomeric differences are however all consistent with a subtle mechanism involving the targeting of oncogenic drivers.

\section{Acknowledgements}

We thank The University of Warwick and Institute of Advanced Study for support of this work. ADF and DHS were supported by EPSRC doctoral studentships.

\section{Notes and references}

1 A. Persidis, Nat. Biotechnol., 1999, 17, 94-95.

2 Y. Cao, R. A. DePinho, M. Ernst and K. Vousden, Nat. Rev. Cancer, 2011, 11, 749-754.

3 H. M. W. Verheul and H. M. Pinedo, Nat. Rev. Cancer, 2007, 7, 475-485.

4 C. E. Meacham and S. J. Morrison, Nature, 2013, 501, 328337.

5 U. S. Eggert, Nat. Chem. Biol., 2013, 9, 206-209.

6 J. A. Lee, M. T. Uhlik, C. M. Moxham, D. Tomandl and D. J. Sall, J. Med. Chem., 2012, 55, 4527-4538.

7 F. Sams-Dodd, Drug Discovery Today, 2013, 18, 211-217.

8 D. C. Swinney and J. Anthony, Nat. Rev. Drug Discovery, 2011, 10, 507-519.

9 J. G. Moffat, J. Rudolph and D. Bailey, Nat. Rev. Drug Discovery, 2014, 13, 588-602.

10 J. M. Lehn, A. Rigault, J. Siegel, J. Harrowfield, B. Chevrier and D. Moras, Proc. Natl. Acad. Sci. U. S. A., 1987, 84, 25652569.

11 J. M. C. A. Kerckhoffs, J. C. Peberdy, I. Meistermann, L. J. Childs, C. J. Isaac, C. R. Pearmund, V. Reudegger, S. Khalid, N. W. Alcock, M. J. Hannon and A. Rodger, Dalton Trans., 2007, 734-742.

12 J. Malina, M. J. Hannon and V. Brabec, Nucleic Acids Res., 2008, 36, 3630-3638.

13 A. D. Richards, A. Rodger, M. J. Hannon and A. Bolhuis, Int. J. Antimicrob. Agents, 2009, 33, 469-472. 
14 L. Cardo, V. Sadovnikova, S. Phongtongpasuk, N. J. Hodges and M. J. Hannon, Chem. Commun., 2011, 47, 6575-6577.

15 H. Yu, M. Li, G. Liu, J. Geng, J. Wang, J. Ren, C. Zhao and X. Qu, Chem. Sci., 2012, 3, 3145-3153.

16 S. E. Howson and P. Scott, Dalton Trans., 2011, 40, 1026810277.

17 R. A. Kaner and P. Scott, Future Med. Chem., 2015, 7, 1-4.

18 S. E. Howson, L. E. N. Allan, N. P. Chmel, G. J. Clarkson, R. van Gorkum and P. Scott, Chem. Commun., 2009, 17271729.

19 S. E. Howson, A. Bolhuis, V. Brabec, G. J. Clarkson, J. Malina, A. Rodger and P. Scott, Nat. Chem., 2012, 4, 31-36.

20 V. Brabec, S. E. Howson, R. A. Kaner, R. M. Lord, J. Malina, R. M. Phillips, Q. M. A. Abdallah, P. C. McGowan, A. Rodger and P. Scott, Chem. Sci., 2013, 4, 4407-4416.

21 M. Li, S. E. Howson, K. Dong, N. Gao, J. Ren, P. Scott and X. Qu, J. Am. Chem. Soc., 2014, 136, 11655-11663.

22 M. Seredyuk, A. B. Gaspar, V. Ksenofontov, Y. Galyametdinov, J. Kusz and P. Gütlich, J. Am. Chem. Soc., 2008, 130, 1431-1439.

23 S. E. Howson, L. E. N. Allan, N. P. Chmel, G. J. Clarkson, R. J. Deeth, A. D. Faulkner, D. H. Simpson and P. Scott, Dalton Trans., 2011, 40, 10416-10433.

24 S. Pathak, M. J. Siciliano, R. Cailleau, C. L. Wiseman and T. C. Hsu, J. Natl. Cancer Inst., 1979, 62, 263-271.

25 F. Bunz, P. M. Hwang, C. Torrance, T. Waldman, Y. Zhang, L. Dillehay, J. Williams, C. Lengauer, K. W. Kinzler and B. Vogelstein, J. Clin. Invest., 1999, 104, 263-269.

26 T. Soussi and C. Beroud, Nat. Rev. Cancer, 2001, 1, 233-239. 27 K. C. Dunn, A. E. Aotaki-Keen, F. R. Putkey and L. M. Hjelmeland, Exp. Eye Res., 1996, 62, 155-170.

28 A. D. Kennedy, M. Otto, K. R. Braughton, A. R. Whitney, L. Chen, B. Mathema, J. R. Mediavilla, K. A. Byrne, L. D. Parkins, F. C. Tenover, B. N. Kreiswirth, J. M. Musser and F. R. DeLeo, Proc. Natl. Acad. Sci. U. S. A., 2008, 105, 1327-1332.

29 A. D. Kennedy, S. F. Porcella, C. Martens, A. R. Whitney, K. R. Braughton, L. Chen, C. T. Craig, F. C. Tenover, B. N. Kreiswirth, J. M. Musser and F. R. DeLeo, J. Clin. Microbiol., 2010, 48, 4504-4511.

30 J. M. Andrews, J. Antimicrob. Chemother., 2001, 48(1), 5-16.

31 S. E. Reynolds, S. F. Nottingham and A. E. Stephens, J. Insect Physiol., 1985, 31, 119-127.
32 J. Malina, P. Scott and V. Brabec, Nucleic Acids Res., 2015, DOI: $10.1093 /$ nar/gkv438.

33 J. Malina, P. Scott and V. Brabec, Dalton Trans., 2015, 44, 14656-14665.

34 V. Brabec, S. E. Howson, R. A. Kaner, R. M. Lord, J. Malina, R. M. Phillips, Q. M. A. Abdallah, P. C. McGowan, A. Rodger and P. Scott, Chem. Sci., 2013, 4, 4407-4416.

35 S. W. G. Tait, G. Ichim and D. R. Green, J. Cell Sci., 2014, 127, 2135-2144.

36 D. Hanahan and R. A. Weinberg, Cell, 2011, 144, 646-674.

37 S. J. Allison and J. Milner, Cell Cycle, 2007, 6, 2669-2677.

38 S. J. Allison, J. R. P. Knight, C. Granchi, R. Rani, F. Minutolo, J. Milner and R. M. Phillips, Oncogenesis, 2014, 3, e102.

39 Apoptosis, Cytotoxicity and Cell Proliferation, 4th edn, ed. Hans-Jürgen Rode, Roche Diagnostics GmbH, Mannheim, Germany, 2008.

40 S. Grimme, S. Ehrlich and L. Goerigk, J. Comput. Chem., 2011, 32, 1456-1465.

41 A. A. Granovsky, Firefly version 7.1.G, http:// www.classic.chem.msu.su/gran/firefly/index.html.

42 M. W. Schmidt, K. K. Baldridge, J. A. Boatz, S. T. Elbert, M. S. Gordon, J. H. Jensen, S. Koseki, N. Matsunaga, K. A. Nguyen, S. Su, T. L. Windus, M. Dupuis and J. A. Montgomery, J. Comput. Chem., 1993, 14, 1347-1363.

43 R. J. Deeth, A. Anastasi, C. Diedrich and K. Randell, Coord. Chem. Rev., 2009, 253, 795-816.

44 R. J. Deeth, N. Fey and B. Williams-Hubbard, J. Comput. Chem., 2005, 26, 123-130.

45 F. Neese, Wiley Interdiscip. Rev.: Comput. Mol. Sci., 2012, 2, 73-78.

46 A. Klamt, J. Phys. Chem., 1995, 99, 2224-2235.

47 P. J. Daborn, N. Waterfield, C. P. Silva, C. P. Y. Au, S. Sharma and R. H. ffrench-Constant, Proc. Natl. Acad. Sci. U. S. A., 2002, 99, 10742-10747.

48 S. E. Howson, L. E. N. Allan, N. P. Chmel, G. J. Clarkson, R. van Gorkum and P. Scott, Chem. Commun., 2009, 17271729.

49 A. D. Faulkner, R. A. Kaner, Q. M. A. Abdallah, G. Clarkson, D. J. Fox, P. Gurnani, S. E. Howson, R. M. Phillips, D. I. Roper, D. H. Simpson and P. Scott, Nat. Chem., 2014, 6, 797-803. 